\title{
Influence of water depth on wave overtopping
}

\author{
Paul van Steeg ${ }^{1, a}$, Menno de Ridder ${ }^{1}$, Alex Capel $^{1}$ and Marcel Bottema ${ }^{2}$ \\ ${ }^{1}$ Deltares, P.O. Box 177, 2600MH Delft, The Netherlands \\ ${ }^{2}$ Ministry of Infrastructure and Water Management, Rijkswaterstaat WVL, P.O. Box 2232, 3500 GE, Utrecht, the Netherlands
}

\begin{abstract}
The wave overtopping discharge during extreme storm conditions largely determines the required crest height in dike reinforcement projects. In case of future sea level rise, crest heights should be increased significantly, which potentially leads to significant costs and environmental and societal consequences. The available empirical design formulas for wave overtopping are based on data sets that show a relatively large scatter, potentially leading to inefficient design of crest level heights. In this paper a novel approach is presented in which the water depth in front of the dike is incorporated in the wave overtopping formulation leading to a lower scatter and in the case of shallow foreshores also a lower required crest height. The present approach is based on the use of an existing overtopping database (CLASH-EurOtop) and additional generated data by conducting physical experiments (Scheldt Flume of Deltares) and numerical experiments (OpenFOAM) in which the water depth was varied systematically for a variety of test conditions. Based on these three approaches, it is concluded that the wave overtopping discharge $(q)$ is dependent on the water depth. Since this dependency is not included in the present wave overtopping formulation, this paper suggests a method to incorporate this dependency in the present existing formulas by implementing an influence factor for water depth $\left(\gamma_{\mathrm{d}}\right)$.
\end{abstract}

\section{Introduction}

\subsection{Background}

Wave overtopping during design conditions is a key aspect in the design of coastal structures which are subject to wave loads. Usually a higher, and thus wider structure, leads to lower overtopping conditions but this may conflict with restrictions related to available space, costs, touristic attractiveness and environmental quality of coasts and banks. Future climate change is expected to lead to sealevel rise and often also to changing wave loads, which together may require the redesign of coastal structures. However, the available empirical design formulas for wave overtopping are based on data sets that show a relatively large scatter, potentially leading to inefficient design of crest levels. Therefore, there is a need to develop approaches in which the wave overtopping conditions can be predicted more accurately resulting in the prevention of unnecessarily high crests of coastal structures, but also to prevent too low crests.

A potential way to improve wave overtopping prediction models is to incorporate the potential influence of the water depth in front of the structure. This influence is to some extent included in the existing empirical formulas for very shallow or extremely shallow water depths but not included for shallow or deep water which is the subject of this paper. The definitions of 'deep', 'shallow', 'very shallow' and 'extremely shallow' are given in Section 1.4 and summarized in Table 2.

\subsection{Technical background: wave overtopping}

Wave overtopping can be characterized in many ways such as the wave overtopping discharge, wave volumes, velocities etc. In this paper the focus is on the wave overtopping discharge which is a generally accepted parameter to describe wave overtopping.

In TAW (2002), the dimensionless wave overtopping discharge is defined as:

$$
\frac{q}{\sqrt{g \cdot H_{m 0}^{3}}}=\frac{0.067}{\sqrt{\tan \alpha}} \cdot \gamma_{b} \cdot \xi_{m-1,0} \cdot e^{-a \frac{R_{c}}{H_{m 0}} \cdot \frac{1}{\xi_{m-1,0} \cdot \gamma_{b} \cdot \gamma_{f} \cdot \gamma_{\beta} \cdot \gamma_{v}}}
$$

With a maximum of

$$
\frac{q}{\sqrt{g \cdot H_{m 0}^{3}}}=0.2 \cdot e^{-b \cdot \frac{R_{c}}{H_{m 0}} \cdot \frac{1}{\gamma_{b} \cdot \gamma_{f}}}
$$

In EurOtop (2018), the dimensionless wave overtopping is slightly differently defined as:

$$
\frac{q}{\sqrt{g \cdot H_{m 0}^{3}}}=\frac{c}{\sqrt{\tan \alpha}} \cdot \gamma_{b} \cdot \xi_{m-1,0} \cdot e^{-\left(d \cdot \frac{R_{c}}{H_{m 0}} \cdot \frac{1}{\xi_{m-1,0} \cdot \gamma_{b} \cdot \gamma_{f} \cdot \gamma_{\beta} \cdot \gamma_{v}}\right)^{1.3}}
$$

With a maximum of 


$$
\frac{q}{\sqrt{g \cdot H_{m 0}^{3}}}=e \cdot e^{-\left(f \cdot \frac{R_{c}}{H_{m 0}} \cdot \frac{1}{\gamma_{b} \cdot \gamma_{f} \cdot \gamma^{*}}\right)^{1.3}}
$$

with

$$
\begin{gathered}
\xi_{m-1,0}=\frac{\tan \alpha}{\sqrt{s_{m-1,0}}} \\
s_{m-1,0}=\frac{H_{m 0}}{L_{m-1,0}}=\frac{2 \pi \cdot H_{m 0}}{g \cdot T_{m-1,0}^{2}}
\end{gathered}
$$

$a, b, c, d, e$ and $f$ are empirical coefficients (-); $g$ is the acceleration due to gravity $\left(\mathrm{m} / \mathrm{s}^{2}\right) ; q$ is the mean wave overtopping discharge $\left(\mathrm{m}^{3} / \mathrm{s} / \mathrm{m}\right) ; H_{\mathrm{m} 0}$ is the spectral significant wave height at the toe of the structure $(\mathrm{m})$; $\xi_{\mathrm{m}-1,0}$ is the breaker parameter $(-) ; R_{\mathrm{c}}$ is the crest height $(\mathrm{m})$, $\alpha$ is the slope angle $\left({ }^{\circ}\right), s_{\mathrm{m}-1,0}$ is the fictious deep water wave steepness (-); $T_{\mathrm{m}-1,0}$ is the spectral wave period at the toe of the structure, and $\gamma_{\beta}, \gamma_{\mathrm{f}}, \gamma_{\mathrm{b}}, \gamma_{\mathrm{v}}, \gamma^{*}$ are influence factors (-) for the angle of wave attack, roughness of slope, presence of berms, presence of crest elements and presence of a storm wall on a slope in case on non-breaking waves.

The reliability of the formulas is given by empirical coefficients $a, b, c, d, e, f$ which are normally distributed stochastic functions. The mean $(\mu)$ and standard deviation $(\sigma)$ as well as the recommended design value according to TAW (2002) and EurOtop (2018) are given in Table 1. The TAW (2002) design values are used in the current Dutch design approach, as described in Rijkswaterstaat (2014). However, this design approach will likely be replaced with a probabilistic approach as discussed in HWBP (2019). For the Dutch statutory periodic flood defence safety assessment, a probabilistic approach is applied as described in MinI\&W (2019).

\begin{tabular}{|l|c|c|c|c|c|c|}
\hline \multirow{2}{*}{} & \multicolumn{2}{|c|}{ TAW (2002) } & \multicolumn{4}{|c|}{ EurOtop (2018) } \\
\cline { 2 - 7 } & $a$ & $b$ & $c$ & $d$ & $e$ & $f$ \\
\hline$\mu$ & 4.75 & 2.6 & 0.023 & 2.7 & 0.09 & 1.5 \\
\hline$\sigma$ & 0.5 & 0.35 & 0.003 & 0.2 & 0.0135 & 0.15 \\
\hline d.v. & 4.25 & 2.25 & 0.026 & 2.5 & 0.1035 & 1.35 \\
\hline
\end{tabular}

Table 1. Overview measured test conditions and results of numerical experiments (d.v. $=$ recommended design value according to TAW (2002) and EurOtop (2018).

As can be seen, both formulations incorporate hydraulic aspects, geometric aspects and the roughness of the slope. The hydraulic conditions are solely characterised by the significant wave height $H_{\mathrm{m} 0}$, the spectral wave period $T_{\mathrm{m}-1.0}$ and the angle of incidence $\beta$ (through influence factor $\gamma_{\beta}$ ). As can be seen, the water depth in front of the structure is not yet incorporated in this approach.

\subsection{TAW (2002) vs. EurOtop(2018)}

The TAW (2002) and EurOtop (2018) formulas for breaking waves (Eq. (1.1) and Eq. (1.3)) and the 90\% confidence bounds based on the conditions on which the expressions have been derived are given in Figure 1. On the horizontal axes, the dimensionless crest height $R^{*}$ is given. The vertical coordinate corresponds to the dimensionless wave overtopping discharge $Q^{*} \cdot R^{*}$ and $Q^{*}$ are defined by:

$$
\begin{aligned}
& R^{*}=\frac{R_{c}}{H_{m 0} \xi_{m-1.0} \cdot \gamma_{b} \cdot \gamma_{f} \cdot \gamma_{\beta} \cdot \gamma_{v}} \\
& Q^{*}=\frac{q}{\sqrt{g H_{m 0}^{3}}} \sqrt{\frac{S_{m-1.0}}{\tan \alpha}} \cdot \frac{1}{\gamma_{b}}
\end{aligned}
$$

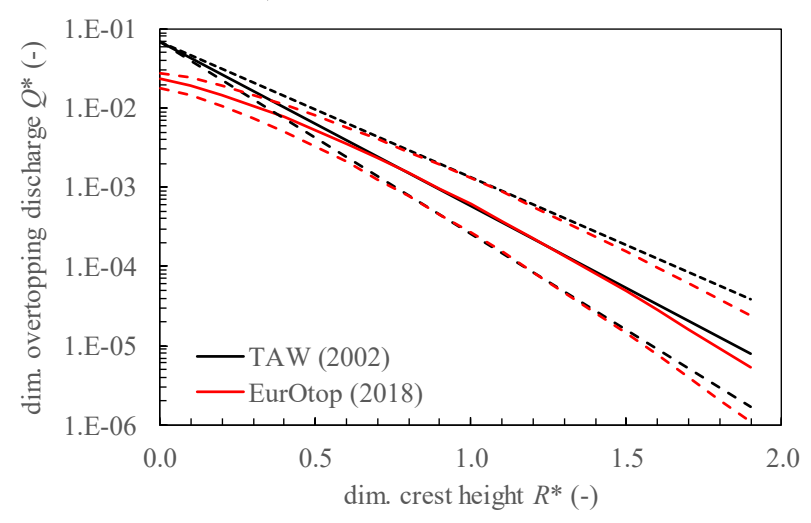

Figure 1. TAW (2002) vs. EurOtop (2018) formula (breaking waves).

Both formulas predict nearly the same results in case $R^{*}>\approx 0.5$ and $\gamma=1$. For situations where $R^{*}<0.5$ the predictions deviate from each other; TAW (2002) then predicts larger overtopping discharges than EurOtop (2018).

\subsection{Technical background: influence of water depth}

The potential influence of water depth is noticed by various researchers of which an overview is given in Deltares (2015) and summarized and complemented below.

WL (1993) suggested an influence factor for a shallow foreshore based on the assumption that higher waves will break on the foreshore resulting in a different wave height distribution. However, WL (1997) concluded, based on results of a physical model, that an extra influence factor due to shallow foreshores is not justified since there is a large uncertainty in the determination of the wave parameters such as $H_{\mathrm{m} 0}$ and $H_{2} \%$ in 1997.

In Szmytiewic et al. (1994), a dataset with smooth slopes is described. This dataset was created by conducting small scale experiments. Szmytiewic et al. (1994) concluded that the run-up height increases as the water depth increases.

Van Steeg et al. (2016) describe a large-scale wave flume experiment in which the roughness characteristics of various placed block revetments were investigated. Van Steeg et al. (2016) concluded that the results indicated a significant influence of the water depth on the wave runup characteristics and recommended to study this aspect in more detail.

Van der Meer et al. (2019) describe a field measurement campaign with a wave overtopping box placed on a real dike. It turned out that the distribution of wave volumes deviated significantly from the expected value found in literature. Van der Meer et al. (2019) 
concluded that the depth-limited wave conditions might have played a role and more research to this aspect was suggested.

Hofland et al. (2017) characterise the ranges of foreshore shallowness based on the ratio of the still water depth near the structure $\left(h_{\mathrm{t}}\right)$ and the offshore wave height in deep water $\left(H_{\mathrm{m} 0 \text {,deep }}\right)$ as indicated in Table 2.

\begin{tabular}{|l|c|l|}
\hline Deep & $4<h_{\mathrm{t}} / H_{\mathrm{m} 0 \text {,deep }}$ & $\begin{array}{l}\text { No breaking according to } \\
\text { Battjes and Groenendijk } \\
(2000) \text { equation }\end{array}$ \\
\hline Shallow & $1<h_{\mathrm{t}} / H_{\mathrm{m} 0 \text {,deep }}<4$ & $\begin{array}{l}\text { Some wave breaking but a } \\
\text { clearly single peaked } \\
\text { spectrum }\end{array}$ \\
\hline $\begin{array}{l}\text { Very } \\
\text { shallow }\end{array}$ & $0.3<h_{\mathrm{t}} / H_{\mathrm{m} 0 \text {,deep }}<1$ & $\begin{array}{l}50-60 \% \text { reduction of wave } \\
\text { height at toe, large amount } \\
\text { of low frequency }\end{array}$ \\
\hline $\begin{array}{l}\text { Extremely } \\
\text { shallow }\end{array}$ & $h_{\mathrm{t}} / H_{\mathrm{m} 0 \text {,deep }}<0.3$ & $\begin{array}{l}\text { Low frequency is } \\
\text { dominant }\end{array}$ \\
\hline
\end{tabular}

Table 2. Ranges of foreshore shallowness as defined by Hofland et al. (2017).

Wave overtopping at very shallow foreshores is described in Van Gent (1999). Extremely shallow foreshores are studied in Altomare et al. (2016) and Chen et al. (2016). The influence of shallow foreshores on wave overtopping is discussed by Goda (2009) who proposed a set of formula's incorporating the foreshore depth based on the analysis of the CLASH database with data with a dimensionless toe depth of $d_{\mathrm{t}} / H_{\mathrm{m} 0 \text {,toe }}>1$. These formulas proposed by Goda (2009) do not include the wave steepness or structure slope angle and cannot be transformed easily into the TAW (2002) or EurOtop (2018) approach.

\subsection{Research approach}

Based on the above described analysis, it is concluded that it is quite probable that the wave overtopping discharge is influenced by the water depth at the toe. However, no sound data is available to quantify this influence. Therefore, three data sets were created: (1) by performing physical model tests in a wave flume, (2) by performing numerical model tests and (3) by studying a large database (CLASH and EurOtop database) containing the data of thousands of experimental wave overtopping experiments. The three approaches are described in Chapters 2-4, analysed in Chapter 5 and discussed in Chapter 6.

\section{Flume experiments}

\subsection{Test set-up}

To systematically vary conditions of the water depth, physical wave overtopping experiments were carried out in the Scheldt Flume of Deltares. This flume has a length of $55 \mathrm{~m}$ (extendable to a length of $110 \mathrm{~m}$ ), a width of 1.0 $\mathrm{m}$ and a height of $1.25 \mathrm{~m}$. The flume is equipped with a Piston type wave board that can generate both regular and irregular waves. The wave board is equipped with an Active Reflection Compensation system; this system prevents re-reflections from the wave board into the flume. During the tests, second order steering is applied to reduce spurious waves.

In the flume a 1:3 slope without berm, toe structure, roughness elements or crest elements was constructed. The (centre) position of the wave board was at $X=0.00 \mathrm{~m}$, the toe of the dike was at $X=36.66 \mathrm{~m}$. In front of the structure was a horizontal smooth concrete bed with a length of $26.79 \mathrm{~m}(X=9.87 \mathrm{~m}-36.66 \mathrm{~m})$ which was $0.090 \mathrm{~m}$ higher than the flume bottom. The transition between the concrete bed and the flume bottom was a smooth 1:10 slope ( $X=$ $8.70 \mathrm{~m}-9.87 \mathrm{~m})$. This bed was needed to be able to generate waves.

The most important variation in the tests was the water depth; this was done by changing the water level and the crest level simultaneously ensuring that the crest height is the same in comparative tests. During the tests the water level was kept constant by using a pump to compensate for overtopping volumes.

Waves were measured at two positions using four resistance type wave gauges at each position. The incident wave conditions were determined for $X=8.00 \mathrm{~m}$ ('deeper water') and $X=35.95 \mathrm{~m}$ ('toe') using the method as described in Zelt and Skjelbreia (1993).

Wave overtopping characteristics were measured by placing one wave gauge at the crest (to identify an overtopping event) and by placing two wave gauges in an overtopping box to measure the water level in that box.

\subsection{Test programme and results}

In the test programme, three dimensionless parameters were varied in a systematic way: the relative crest height

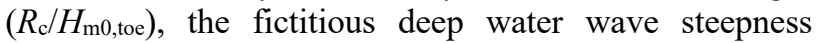
$\left(s_{\mathrm{m}-1.0}\right)$ and the relative water depth at the toe $\left(h_{\mathrm{t}} / H_{\mathrm{m} 0, \text { toe }}\right)$. The following variations were applied:

$$
\begin{array}{lll}
- & R_{\mathrm{c}} / H_{\mathrm{m} 0 \text {,toe }} & \approx\{2.5 ; 1.8\} \\
\text { - } & S \mathrm{~m}-1.0 & \approx\{0.015 ; 0.025 ; 0.035 ; 0.045\} \\
\text { - } & h_{\mathrm{t}} / H_{\mathrm{m} 0 \text {,toe }} & \approx\{1.0 ; 1.2 ; 1.4 ; 1.6 ; 2.2\}
\end{array}
$$

It was aimed to have the measured significant wave height at the toe as close as possible to a value of $H_{\mathrm{m} 0 \text {,toe }}=$ $0.15 \mathrm{~m}$ which was not in all cases possible. At the wave board, wave trains with a JONSWAP spectrum and approximately 1000 waves were generated. During calibration tests without a structure, optimal wave steering conditions were applied to obtain the required conditions at the position of the toe of the dike (target parameters: $H_{\mathrm{m} 0 \text {,toe }}$ and $\left.T_{\mathrm{m}-1.0 \text {,toe }}\right)$. An overview of the measured test conditions and dimensionless parameters is given in Table 3.

An impression of the experiments is given in Figure 2 and Figure 3. More background information of the experiments is given in Deltares (2018). 


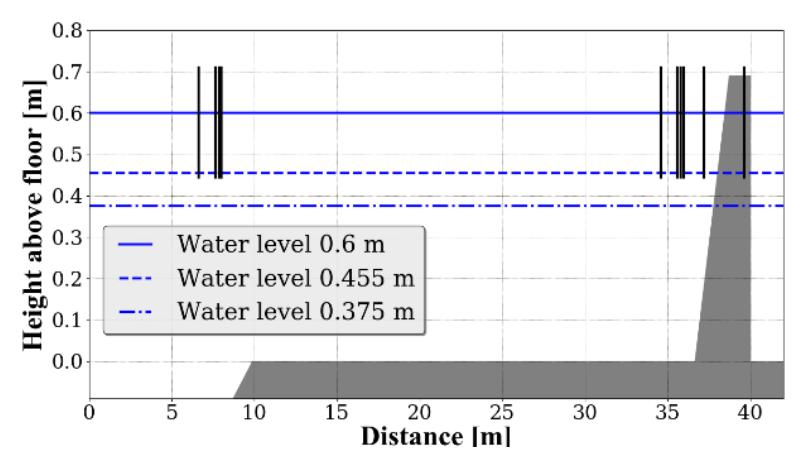

Figure 2. Schematisation of test setup.



Figure 3. Impression of the Scheldt Flume of Deltares.

\begin{tabular}{|c|c|c|c|c|c|c|c|c|c|}
\hline test & $h_{\mathrm{t}} / R_{\mathrm{c}}$ & $R_{\mathrm{c}} \mathrm{d} \boldsymbol{H}_{\mathrm{m} 0, \text { toe }}$ & $s_{\mathrm{m}-1.0}$ & $h_{\mathrm{t}}$ & $R_{\mathrm{c}}$ & $H_{\mathrm{m} 0, \text { toe }}$ & $T_{\mathrm{m}-1.0, \mathrm{t} \text { toe }}$ & $q$ & break \\
\hline id & $(-)$ & $(-)$ & $(-)$ & (m) & (m) & (m) & (s) & $\left(\mathbf{m}^{3} / \mathbf{s} / \mathbf{m}\right)$ & ing \\
\hline T101 & \multirow{6}{*}{1.6} & 2.50 & 0.015 & \multirow{6}{*}{0.600} & \multirow{6}{*}{0.375} & 0.150 & 2.52 & $2.16 \mathrm{E}-04$ & $\mathrm{n}$ \\
\hline T102 & & 2.48 & 0.024 & & & 0.151 & 2.00 & $1.49 \mathrm{E}-04$ & $\mathrm{n}$ \\
\hline $\mathrm{T} 103$ & & 2.50 & 0.035 & & & 0.150 & 1.66 & $4.80 \mathrm{E}-05$ & $\mathrm{y}$ \\
\hline T104 & & 2.52 & \begin{tabular}{|l|} 
\\
\end{tabular} & & & 0.149 & 1.48 & $3.23 \mathrm{E}-05$ & $\mathrm{y}$ \\
\hline $\mathrm{T} 113$ & & 2.62 & 0.034 & & & 0.143 & 1.65 & $3.83 \mathrm{E}-05$ & $\mathrm{y}$ \\
\hline T114 & & 2.70 & 0.042 & & & 0.139 & 1.46 & 7.37E-06 & y \\
\hline $\mathrm{T} 201$ & \multirow{6}{*}{2.2} & 1.81 & 0.015 & \multirow{6}{*}{0.600} & \multirow{6}{*}{0.274} & 0.151 & 2.52 & $1.09 \mathrm{E}-03$ & $\mathrm{n}$ \\
\hline T202 & & 1.83 & 0.024 & & & 0.150 & 2.00 & $8.46 \mathrm{E}-04$ & $\mathrm{n}$ \\
\hline T203 & & 1.81 & 0.035 & & & 0.151 & 1.65 & $4.12 \mathrm{E}-04$ & $\mathrm{y}$ \\
\hline $\mathrm{T} 204$ & & 1.81 & 0.045 & & & 0.151 & 1.47 & $2.87 \mathrm{E}-04$ & $\mathrm{y}$ \\
\hline $\mathrm{T} 213$ & & 1.90 & 0.034 & & & 0.144 & 1.64 & $3.35 \mathrm{E}-04$ & $\mathrm{y}$ \\
\hline T214 & & 1.94 & 0.043 & & & 0.141 & 1.46 & $1.74 \mathrm{E}-04$ & $\mathrm{y}$ \\
\hline $\mathrm{T} 105$ & \multirow{6}{*}{1.2} & 2.48 & 0.015 & \multirow{6}{*}{0.455} & \multirow{6}{*}{0.375} & 0.151 & 2.53 & $2.16 \mathrm{E}-04$ & $\mathrm{n}$ \\
\hline $\mathrm{T} 106$ & & 2.52 & 0.025 & & & 0.149 & 1.96 & $4.87 \mathrm{E}-05$ & $\mathrm{n}$ \\
\hline $\mathrm{T} 107$ & & 2.52 & 0.035 & & & 0.149 & 1.66 & $1.95 \mathrm{E}-05$ & $\mathrm{y}$ \\
\hline T108 & & 2.50 & 0.044 & & & 0.150 & 1.47 & \begin{tabular}{|l|}
$1.04 \mathrm{E}-05$ \\
\end{tabular} & $y$ \\
\hline $\mathrm{T} 115$ & & 2.64 & 0.033 & & & 0.142 & 1.65 & $1.54 \mathrm{E}-05$ & $\mathrm{y}$ \\
\hline $\mathrm{T} 116$ & & 2.72 & 0.042 & & & 0.138 & 1.45 & 7.23E-06 & $\mathrm{y}$ \\
\hline T205 & \multirow{6}{*}{1.7} & 1.83 & 0.015 & \multirow{6}{*}{0.455} & \multirow{6}{*}{0.274} & 0.150 & 2.53 & $1.03 \mathrm{E}-03$ & $\mathrm{n}$ \\
\hline T206 & & 1.84 & 0.025 & & & 0.149 & 1.96 & \begin{tabular}{|l|l}
$6.25 \mathrm{E}-04$ \\
\end{tabular} & $\mathrm{n}$ \\
\hline T207 & & 1.84 & 0.035 & & & 0.149 & 1.66 & \begin{tabular}{|l|l|}
$2.77 \mathrm{E}-04$ \\
\end{tabular} & $\mathrm{y}$ \\
\hline T208 & & 1.83 & \begin{tabular}{|l|} 
\\
\end{tabular} & & & 0.150 & 1.47 & \begin{tabular}{|l|l|}
$1.31 \mathrm{E}-04$ \\
\end{tabular} & $\mathrm{y}$ \\
\hline $\mathrm{T} 215$ & & 1.93 & 0.034 & & & 0.142 & 1.65 & $2.23 \mathrm{E}-04$ & $\mathrm{y}$ \\
\hline T216 & & 1.99 & \begin{tabular}{|l|l|}
0.042 \\
\end{tabular} & & & 0.138 & 1.45 & \begin{tabular}{|l|}
$1.00 \mathrm{E}-04$ \\
\end{tabular} & $\mathrm{y}$ \\
\hline T109 & \multirow{4}{*}{1.0} & 2.50 & 0.015 & \multirow{4}{*}{0.375} & \multirow{4}{*}{0.375} & 0.150 & 2.57 & \begin{tabular}{|l|l|}
$1.82 \mathrm{E}-04$ \\
\end{tabular} & $\mathrm{n}$ \\
\hline T110 & & 2.50 & \begin{tabular}{|l|l|} 
\\
\end{tabular} & & & 0.150 & 1.99 & $2.05 \mathrm{E}-05$ & $\mathrm{n}$ \\
\hline T111 & & 2.64 & 0.033 & & & 0.142 & 1.66 & \begin{tabular}{|l|l|}
$8.23 \mathrm{E}-06$ \\
\end{tabular} & $\mathrm{y}$ \\
\hline T112 & & 2.72 & 0.042 & & & 0.138 & 1.45 & $2.19 \mathrm{E}-06$ & $\mathrm{y}$ \\
\hline T209 & \multirow{4}{*}{1.} & 1.83 & \begin{tabular}{|l|}
0.014 \\
\end{tabular} & \multirow{4}{*}{0.375} & \multirow{4}{*}{0.274} & 0.150 & 2.58 & \begin{tabular}{|l|l|}
$9.4 \mathrm{E}-04$ \\
\end{tabular} & $\mathrm{n}$ \\
\hline $\mathrm{T} 210$ & & 1.84 & \begin{tabular}{|l|l|} 
\\
\end{tabular} & & & 0.149 & 1.99 & \begin{tabular}{|l|l|}
$3.49 \mathrm{E}-04$ \\
\end{tabular} & $\mathrm{n}$ \\
\hline T211 & & 1.93 & \begin{tabular}{|l|}
0.034 \\
\end{tabular} & & & 0.142 & 1.63 & $1.28 \mathrm{E}-04$ & $\mathrm{y}$ \\
\hline T212 & & 1.99 & $\mid$\begin{tabular}{|c|}
$\mid 0.042$ \\
\end{tabular} & & & 0.138 & 1.44 & $|5.21 \mathrm{E}-05|$ & $\mathrm{y}$ \\
\hline
\end{tabular}

Table 3. Overview of measured test conditions and results of physical experiments (Column 'breaking' indicates whether results are included in the analysis of Chapter 5, see Section

\section{Numerical experiments}

\subsection{Introduction}

In addition to the physical experiments in the Scheldt Flume, numerical experiments were performed. The aim was threefold: (1) to verify whether the numerical model could reproduce the results obtained in the Scheldt Flume, (2) to gather data with different slope angles than tested in the Scheldt Flume, (3) to be able to measure and analyse aspects that have not been measured in the Scheldt Flume.

\subsection{Test set-up}

Numerical experiments were carried out by performing simulations within two computational domains which were run separately to reduce calculation time. For the wave transformation within the domain, use was made of OceanWave3D (OCW) which is described in Paulsen et al. (2014). For overtopping calculations, the Waves2Foam module (Jacobsen et al., 2012) of the Volume-Of-Fluid model OpenFoam is used.

The numerical test set-up is based on the experimental test set-up in the Scheldt Flume. The positions of the wave board, toe of the structure and elevated bottom were equal to the test set-up in the Scheldt Flume. The computational domain of OCW is between $X=0 \mathrm{~m}$ and $X=42 \mathrm{~m}$. The computational domain of the OpenFoam module is between $X=30$ and $X=45 \mathrm{~m}$. In OpenFoam a computational grid with a spatial varying resolution is applied to minimize computational time. A calibration was performed on the viscosity (representing the turbulent eddy viscosity) to compensate for the lack of turbulence dissipation.

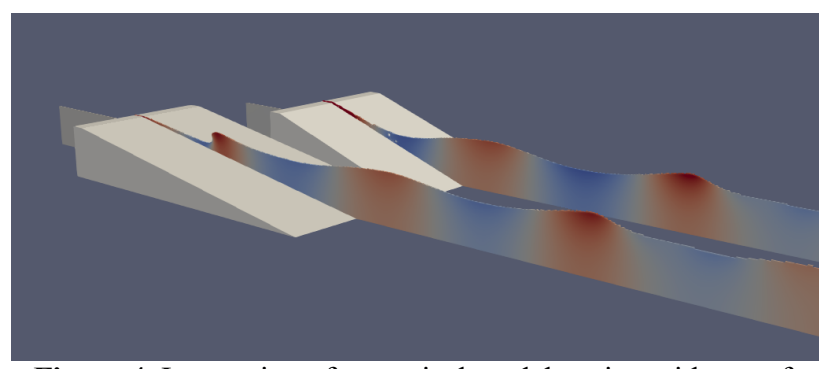

Figure 4. Impression of numerical model testing with use of OpenFoam.

The numerical model data were validated with the experimental results of eight Scheldt Flume overtopping tests, while applying identical wave steering files to both the physical and numerical model.

Incident wave conditions at the toe position were determined by repeating the simulations while no structure was placed in the computational domain. A wave absorbing numerical sponge layer was used to absorb incident waves and to minimize reflections. Despite these measures, long waves were still reflecting a bit which was compensated for by assuming a reflection coefficient of 0.5 for all waves with a frequency lower than $f_{\mathrm{p}} / 2$ with $f_{\mathrm{p}}$ the peak frequency $(\mathrm{Hz})$. This is illustrated in Figure 5. 
Wave overtopping conditions were determined at the crest of the dike.

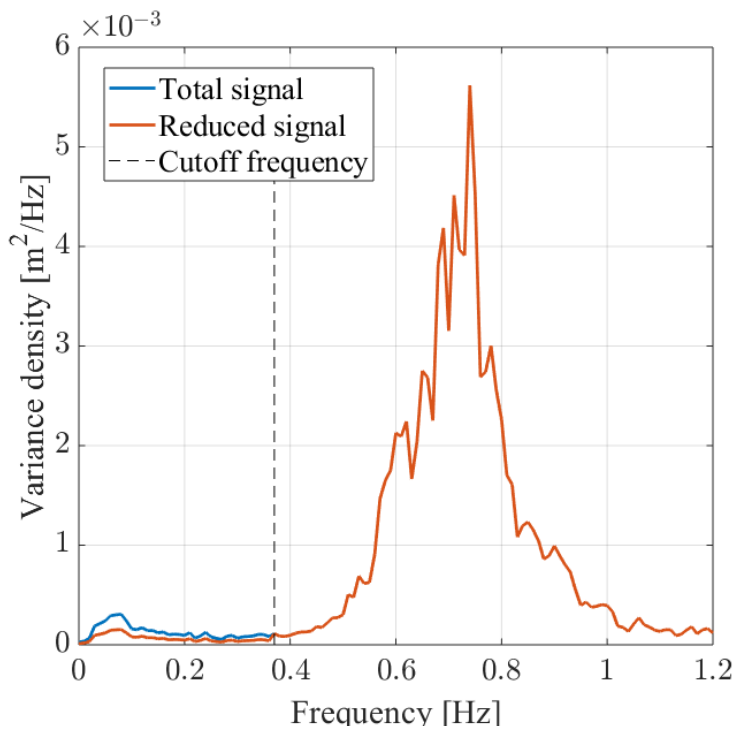

Figure 5. Impression of reducing the measured signal for $f_{\mathrm{p}} / 2$.

\subsection{Test program and results}

In the test programme three parameters were varied systematically: the slope angle of the structure $(\cot \alpha)$, the expected wave overtopping discharge according to TAW (2000) ( $\left.q_{\mathrm{TAW}}\right)$ resulting in a required crest level $\left(R_{\mathrm{c}}\right)$; and the water depth at the toe of the structure $\left(h_{\mathrm{t}}\right)$. The following variations were applied:

$$
\begin{aligned}
\cot \alpha & =\{3 ; 4 ; 6\} \\
q_{\mathrm{TAW}} & \approx\{2 ; 10\} 1 / \mathrm{s} / \mathrm{m} \text { at assumed model scaling } \\
& \quad \text { factor (length scaling) of } n_{\mathrm{L}}=10 \\
h_{\mathrm{t}} & =\{0.375 ; 0.455 ; 0.600\} \mathrm{m}
\end{aligned}
$$

It was aimed to have the measured significant wave height at the toe as close as possible to a value of $H_{\mathrm{m} 0 \text {,toe }}=$ $0.13 \mathrm{~m}$. At the fictitious waveboard, a wave train with a JONSWAP spectrum and approximately 1000 waves was generated. The steering files were identical to those used in the physical experiments. An overview of the measured test conditions and dimensionless parameters is given in

\begin{tabular}{|c|c|c|c|c|c|c|c|c|c|c|}
\hline test & $h_{\mathrm{t}} / R_{\mathrm{c}}$ & $R_{\mathrm{c}} / H_{\mathrm{m} 0, \text { toe }}$ & $s_{\mathrm{m}-1.0}$ & $h_{\mathrm{t}}$ & $R_{\mathrm{c}}$ & $\cot \alpha$ & $H_{\mathrm{m} 0, \text { toe }}$ & $T_{\text {m-1.0,toe }}$ & $q$ & break- \\
\hline id & $(-)$ & $(-)$ & $(-)$ & (m) & (m) & $(-)$ & (m) & (s) & $\left(\mathrm{m}^{3} / \mathrm{s} / \mathrm{m}\right)$ & ing \\
\hline T114_1 & 2.0 & 2.31 & 0.033 & \multirow{6}{*}{0.600} & 0.294 & 3 & 0.127 & 1.57 & $1.02 \mathrm{E}-04$ & $y$ \\
\hline T114_2 & 2.8 & 1.70 & 0.033 & & 0.215 & 4 & 0.127 & 1.57 & 1.07E-04 & $y$ \\
\hline T114_3 & 4.3 & 1.09 & 0.033 & & 0.139 & 6 & 0.127 & 1.57 & $1.13 \mathrm{E}-04$ & $y$ \\
\hline T214_1 & 2.8 & 1.71 & 0.033 & & 0.217 & 3 & 0.127 & 1.57 & 4.54E-04 & $y$ \\
\hline T214_2 & 3.8 & 1.24 & 0.033 & & 0.158 & 4 & 0.127 & 1.57 & $4.88 \mathrm{E}-04$ & $y$ \\
\hline T214_3 & 6.0 & 0.79 & 0.033 & & 0.100 & 6 & 0.127 & 1.57 & $4.39 \mathrm{E}-04$ & $\mathrm{y}$ \\
\hline T116_1 & 1.5 & 2.25 & 0.032 & \multirow{6}{*}{0.455} & 0.294 & 3 & 0.131 & 1.62 & $6.50 \mathrm{E}-05$ & $\mathrm{n}$ \\
\hline T116_2 & 2.1 & 1.65 & 0.032 & & 0.215 & 4 & 0.131 & 1.62 & 9.42E-05 & $\mathrm{y}$ \\
\hline T116_3 & 3.3 & 1.06 & 0.032 & & 0.139 & 6 & 0.131 & 1.62 & $1.08 \mathrm{E}-04$ & $y$ \\
\hline T216_1 & 2.1 & 1.66 & 0.032 & & 0.217 & 3 & 0.131 & 1.62 & 3.61E-04 & $n$ \\
\hline T216_2 & 2.9 & 1.21 & 0.032 & & 0.158 & 4 & 0.131 & 1.62 & 4.21E-04 & $\mathrm{y}$ \\
\hline T216_3 & 4.5 & 0.77 & 0.032 & & 0.100 & 6 & 0.131 & 1.62 & 4.11E-04 & $y$ \\
\hline T112_1 & 1.3 & 2.27 & 0.033 & \multirow{6}{*}{0.375} & 0.294 & 3 & 0.130 & 1.58 & 4.06E-05 & $\mathrm{y}$ \\
\hline T112_2 & 1.7 & 1.66 & 0.033 & & 0.215 & 4 & 0.130 & 1.58 & 4.45E-05 & $\mathrm{y}$ \\
\hline T112_3 & 2.7 & 1.07 & 0.033 & & 0.139 & 6 & 0.130 & 1.58 & 4.94E-05 & $y$ \\
\hline T212_1 & 1.7 & 1.68 & 0.033 & & 0.217 & 3 & 0.130 & 1.58 & 2.37E-04 & $\mathrm{y}$ \\
\hline T212_2 & 2.4 & 1.22 & 0.033 & & 0.158 & 4 & 0.130 & 1.58 & $2.51 \mathrm{E}-04$ & $y$ \\
\hline T212_3 & 3.7 & 0.77 & 0.033 & & 0.100 & 6 & 0.130 & 1.58 & $2.58 \mathrm{E}-04$ & y \\
\hline
\end{tabular}
Table 4.

More background information of the numerical experiments is given in Deltares (2019).
Table 4. Overview measured test conditions and results of numerical experiments. (Column 'breaking' indicates whether

the test results are included in the analysis of Chapter 5).

\section{Selection of tests from CLASH and EurOtop database}

\subsection{Introduction to the CLASH and EurOtop database}

Within the EU project CLASH a wave overtopping database containing 10.532 tests from 163 independent test series was collected and described in Steendam et al. (2004) and Van der Meer et al. (2009). The data are described with 31 parameters containing the hydraulic conditions, overtopping conditions, foreshore, geometry and roughness of the structure, the reliability and complexity of the tests and, highly relevant for this study, the water depth in front of the structure. An impression of these parameters is given in Figure 6.

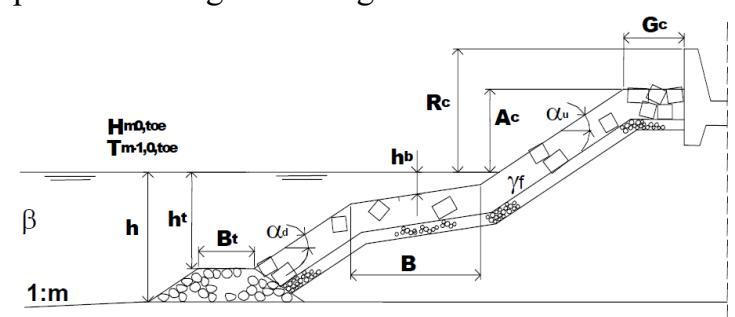

Figure 6. Geometric parameters used in the CLASH database (source: Steendam et al., 2004).

An extended CLASH database is available and referred to here as the CLASH-EurOtop database.

\subsection{Selection of tests}

To study the influence of the water depth on the wave overtopping discharge, specific tests within the CLASH and the CLASH-EurOtop database were selected. To this end, selection criteria were defined which are summarized in Table 5 and described below.

The reliability of the test results should be high. The CLASH database categorises this by using a score from 1 
to 4 with 1 being the most reliable. Only tests with a reliability score of 1 were selected.

The complexity of the structure should be low to avoid interference of other aspects. The CLASH database categorises this by using a score from 1 to 4 with 1 being the lowest complexity. Only tests with a complexity score of 1 were selected.

Tested structures should not have any roughness $\left(\gamma_{\mathrm{f}}=\right.$ $1)$, a crest width $\left(G_{\mathrm{c}}>0\right)$, a crest wall $\left(R_{\mathrm{c}}-A_{\mathrm{c}}>0\right)$, a toe structure $\left(B_{\mathrm{t}}>0\right)$ or a berm $(B>0)$ to avoid the influence of roughness, crest widths, crest walls, a toe structure or a berm on the overtopping discharge.

Tests with a measured overtopping discharge equal to zero $(q=0)$ were not selected.

The spectral wave period at the toe $T_{\mathrm{m}-1.0 \text {,toe }}$ should have been determined directly by spectral analysis and not indirectly by measuring the peak period $T_{\mathrm{p}}$ and by assuming a ratio of $T_{\mathrm{p}, \text { toe }} / T_{\mathrm{m}-1.0 \text {, toe }}=1.10$ (which is an assumption that is not necessarily valid for shallow water). Therefore, all tests with a ratio of exactly $T_{\mathrm{p}, \text { toe }} / T_{\mathrm{m}-1.0, \text { toe }}=$ 1.10 were excluded from the test selection. For the remaining tests it is unclear whether the $T_{\mathrm{m}-1.0}$ was determined directly or by calculating this with the use of computational models such as SWAN. Note that SWAN is not always capable of accurately computing the $T_{\mathrm{m}-1.0 \text {,toe }}$ for shallow water conditions due to the lack of transfer of energy to lower frequencies.

Tests where structures with extremely steep slopes were used were not selected either, as were tests with very steep foreshores.

Finally, only tests that are in the 'breaking' part of the TAW (2002) formula (Eq (1.1)) were selected.

\begin{tabular}{|c|c|c|}
\hline Description & id & Value \\
\hline reliability should be high & RF & $=1$ \\
\hline complexity should be low & $\mathrm{CF}$ & $=1$ \\
\hline no roughness & $\gamma_{\mathrm{f}}$ & $=1$ \\
\hline No crest width & $G_{\mathrm{c}}$ & $=0$ \\
\hline No oblique wave attack & $\beta$ & $=0$ \\
\hline No crest walls & $R_{\mathrm{c}}-A_{\mathrm{c}}$ & $=0$ \\
\hline No toe structure & $B_{\mathrm{t}}$ & $=0$ \\
\hline No berm & $B$ & $=0$ \\
\hline No test without overtopping & $Q$ & $\neq 0$ \\
\hline$T_{\mathrm{m}-1.0}$ is measured & $T_{\text {ptoe }} / T_{\mathrm{m}-1.0 \text { toe }}$ & $\neq 1.10$ \\
\hline No extremely steep slope & $\cot \alpha_{\mathrm{excl}}$ & $>0.2$ \\
\hline No very steep foreshores & $m$ & $\geq 30$ \\
\hline Only 'breaking waves' & \multicolumn{2}{|c|}{ TAW criteria $^{1}$} \\
\hline
\end{tabular}

\section{Analysis}

\subsection{Introduction}

The three datasets (physical model tests, numerical model tests and databases) were analysed integrally by comparing this with the TAW (2002) and the EurOtop (2018) formula. This is only done for tests that are within or very close to the breaking criterium of the TAW (2002) formula (Eq. (1.1)) as indicated in the last column of Table 3 and Table 4.

\subsection{Overview of selected tests for analysis}

The physical model experiments, as described in Chapter 2, consist of 32 tests. Twenty of those tests, as indicated in Table 3 , are within or very near to the 'breaking criterium' according to the TAW (2002) formulation (see Eq. (1.1) and are used in the analysis of this paper.

The numerical experiments, as described in Chapter 3, consist of eighteen tests. Sixteen of those, as indicated in Table 4, are within or very near to the 'breaking criterium' according to the TAW (2002) formulation (see Eq. (1.1)) and are used in the analysis of this paper.

The original CLASH database contains 10.532 tests. After applying the selection procedure as described in Section 4.2, 52 tests of eight different sources remained. Applying the same procedure to the CLASH-EurOtop database led to the same 52 tests plus five additional tests. These five additional tests are all from the same source (Victor and Troch, 2011). The total number of tests used from the CLASH database and CLASH-EurOtop database is thus 57 tests from nine different sources.

An overview of the data used in the analysis in this paper is given in Table 6 . The information of the $4^{\text {th }}$ and $5^{\text {th }}$ column of Table 6 (number of outliers and number of tests with $R^{*}<0.5$ ) will be explained in Section 5.6.

\begin{tabular}{|c|c|c|c|c|c|}
\hline source & id & $\underset{\#}{\stackrel{0}{*}}$ & 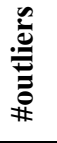 & $\begin{array}{l}\stackrel{n}{0} \\
\stackrel{v}{v} \\
\text { *o }\end{array}$ & 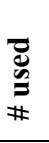 \\
\hline This paper (Scheldt Fl.) & vSt. & 20 & $\mathbf{0}$ & $\mathbf{0}$ & 20 \\
\hline This paper (OpenFoam) & O.Fo & 16 & $\mathbf{0}$ & $\mathbf{0}$ & 16 \\
\hline Coates et al. (1997) & Coa. & 9 & 8 & 0 & 1 \\
\hline Oumeraci et al. (2001) & Oum. & 14 & 0 & 0 & 14 \\
\hline $\begin{array}{l}\text { Schüttrumpf \& Murphy } \\
(2000)\end{array}$ & S\&M & 2 & 0 & 0 & 2 \\
\hline Schüttrumpf (2001) & Sch. & 6 & 0 & 6 & 0 \\
\hline $\begin{array}{l}\text { Van der Meer \& de Waal } \\
\text { (1993) }\end{array}$ & $\mathrm{M} \& \mathrm{~W}$ & 4 & 1 & 0 & 3 \\
\hline Van Gent (1999) & vGe. & 2 & 0 & 0 & 2 \\
\hline Classified (id 956) & Cl.1 & 2 & 2 & 0 & 0 \\
\hline Classified (id 959) & $\mathrm{Cl} .2$ & 13 & 0 & 0 & 13 \\
\hline Victor and Troch (2011) & $\mathrm{V} \& \mathrm{~T}$ & 5 & 0 & 5 & 0 \\
\hline \multicolumn{2}{|c|}{$\begin{array}{l}\text { Total CLASH / CLASH-EurOtop } \\
\text { databases }\end{array}$} & 57 & 11 & 11 & 35 \\
\hline \multicolumn{2}{|l|}{ Total all } & 93 & 11 & 11 & 71 \\
\hline
\end{tabular}

Table 6. Overview of data sources used for analysis. The last column indicates the number of tests that were used to obtain Eq. (1.12).

The ranges of the various parameters of the selected tests are indicated in Figures 7-10.

In Figure 7 the dimensionless crest height $R^{*}$ (see Eq. (1.7)) is plotted against the dimensionless wave overtopping discharge $Q^{*}$ (see Eq. (1.8)). The selected data are plotted together with the TAW (2002) (Eq. (1.1)) and EurOtop (2018) formula (Eq. (1.3)) for comparison. The 5\% confidence bounds of TAW (2002) and EurOtop 
(2018) are also given (dashed lines) to obtain a feeling of the spreading around these formulas.

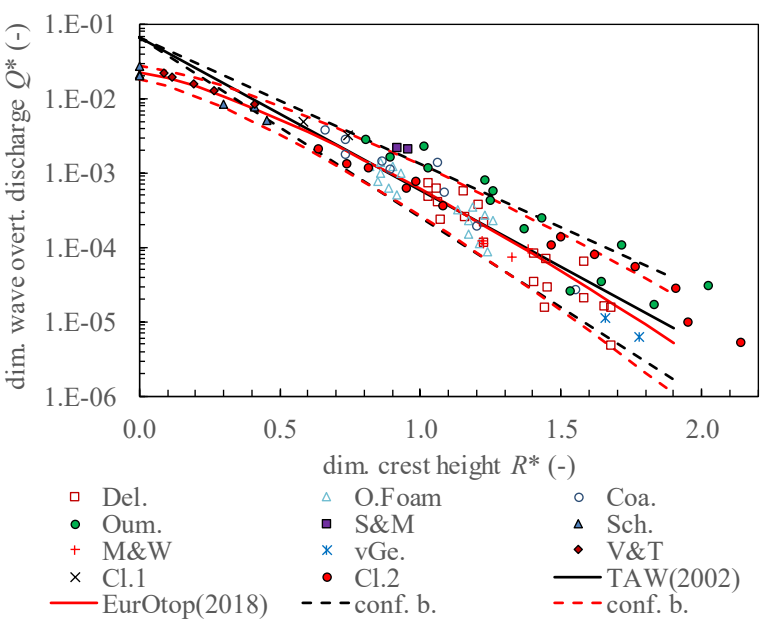

Figure 7. Dimensionless wave overtopping discharge $Q^{*}$ as function of dimensionless crest height $R^{*}$ for all data.

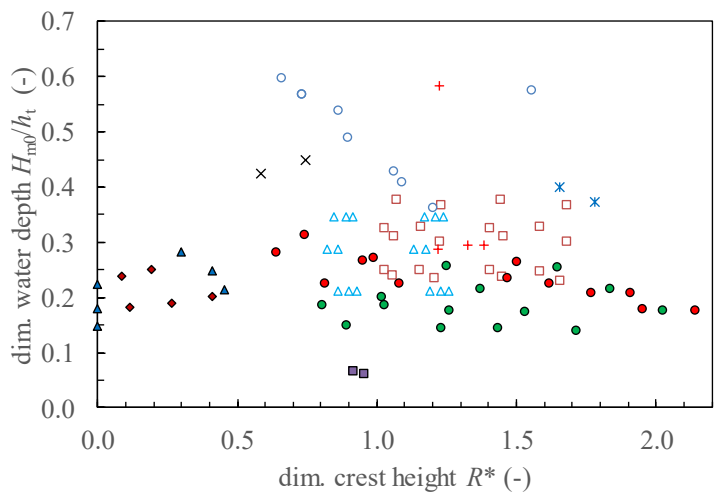

Figure 8. Dimensionless water depth $H_{\mathrm{m} 0} / d$ vs. dimensionless crest height $R^{*}$ for all data (see Figure 7 for legend).

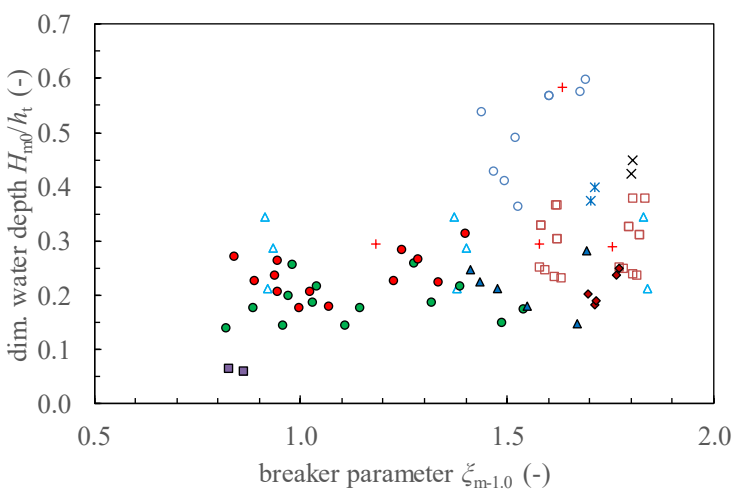

Figure 9. Dimensionless water depth $H_{\mathrm{m} 0} / d$ vs. breaker parameter $\xi_{\mathrm{m}-1.0}$ for all data (see Figure 7 for legend).

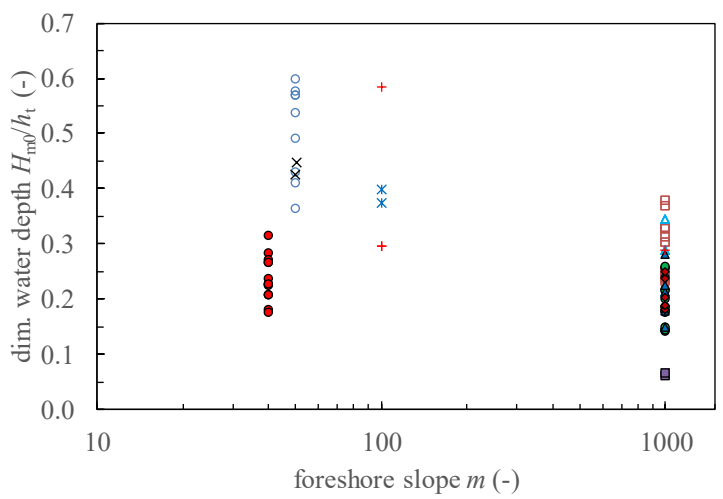

Figure 10. Foreshore slope $m$ vs. dimensionless water depth $H_{\mathrm{m} 0} / d$ for all data (see Figure 7 for legend).

\subsection{Comparison of selected data with TAW (2002) and EurOtop (2018)}

As a next step, the selected data set is split in different sub-classes in terms of relative water depth. In Figure 1113, these sub-classes are compared with the TAW (2002) and Eurotop (2018) formulas. During the analysis, eleven outliers from the CLASH / CLASH-EurOtop database were identified and excluded from the data and are not shown in Figure 13. These outliers are discussed in Section 5.6.

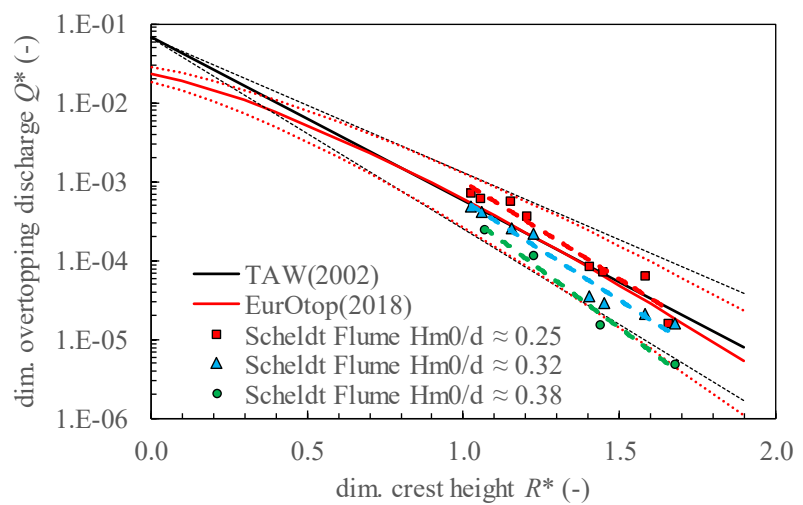

Figure 11. Wave overtopping data derived from Scheldt Flume.

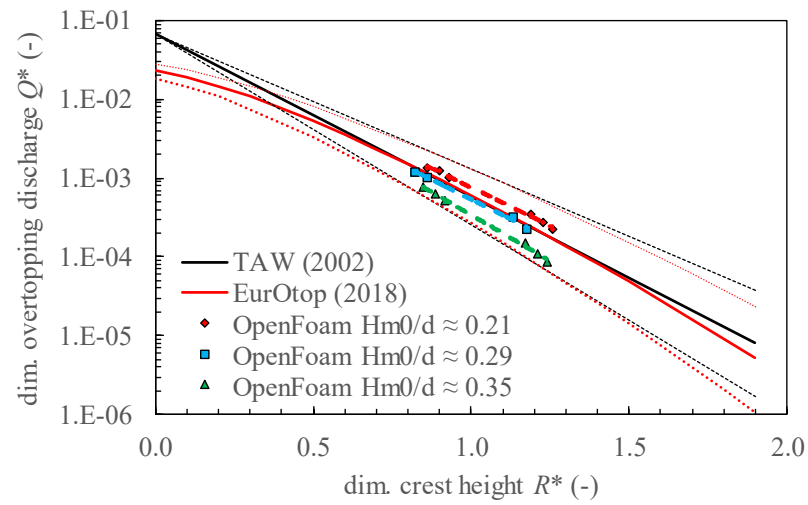

Figure 12. Wave overtopping data derived from OpenFoam. 


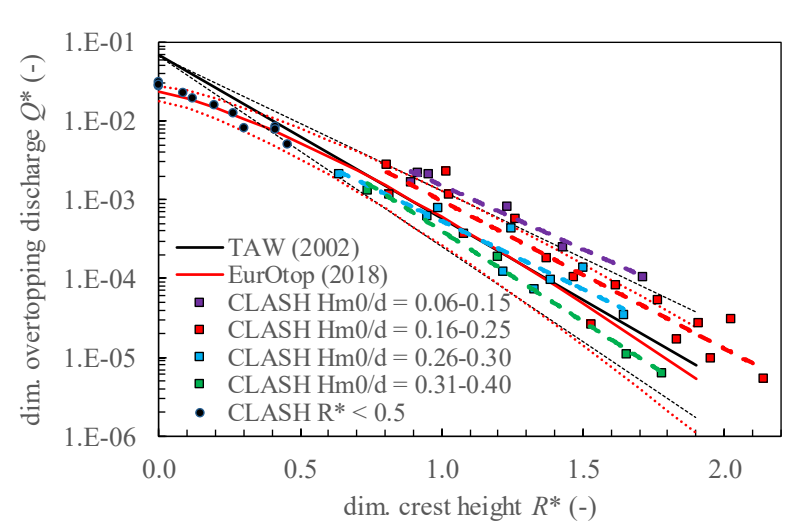

Figure 13. Wave overtopping data derived from CLASH/CLASH-EurOtop database (outliers are not shown, outliers and data with $R^{*}<0.5$ are not included in the trendlines).

From Figure 11, Figure 12 and Figure 13 it can clearly be seen that, for higher value of $H_{\mathrm{m} 0 \text { toe }} / h_{\mathrm{t}}$, the dimensionless wave overtopping discharge $Q^{*}$ is less, indicating an influence of the water depth at the toe of the structure. This is the case for data derived from the Scheldt Flume experiments, the numerical OpenFoam experiments and the data derived from the CLASH/CLASH-EurOtop database.

Although this trend can be seen clearly it is noted that the $H_{\mathrm{m} 0 \text {,toe }} / h_{\mathrm{t}}$ values are slightly different for each Scheldt Flume test and for each OpenFoam test. The range of $H_{\mathrm{m} 0 \text {,toe }} / h_{\mathrm{t}}$ values of the CLASH/CLASH-EurOtop database data is quite large, and therefore a range of $H_{\mathrm{m} 0 \text {, toe }} / h_{\mathrm{t}}$ is given for each subset (e.g. $H_{\mathrm{m} 0 \text {,toe }} / h_{\mathrm{t}}=0.06-0.15$ ).

\subsection{Introduction of influence factor for water depth $Y_{d}$ in TAW (2002)}

To include the influence of the water depth, an influence factor $\gamma_{\mathrm{d}}$ is introduced and implemented in the TAW (2002) formula (Eq. 1) in the same way as the influence factors for berms $\left(\gamma_{\mathrm{b}}\right)$, oblique wave angle $\left(\gamma_{\beta}\right)$, crest walls $\left(\gamma_{v}\right)$ and roughness $\left(\gamma_{\mathrm{f}}\right)$. Since all considered tests are without berms, roughness, crest walls and perpendicular wave attack, these influence factors are considered as:

$$
\gamma_{b}=\gamma_{\beta}=\gamma_{v}=\gamma_{f}=1
$$

Applying the introduced influence factor for water depth $\gamma_{\text {d }}$, Eq. (1.1) can be rewritten as follows:

$$
\gamma_{d, \text { TAl }}=-4.75 \cdot \frac{R_{c}}{H_{m 0} \cdot \xi_{m-1.0}}\left[\ln \left(\frac{\sqrt{\tan \alpha}}{0.067 \xi_{m-1.0}} \cdot \frac{q}{\sqrt{g H_{m 0}^{3}}}\right)\right]^{-1}
$$

The dimensionless crest height as described by Eq. (1.7) can be rewritten as:

$$
R^{*}=\frac{R_{c}}{H_{m 0} \cdot \xi_{m-1.0} \cdot \gamma_{b} \cdot \gamma_{f} \cdot \gamma_{\beta} \cdot \gamma_{v} \cdot \gamma_{d}}
$$

For all physical tests, numerical tests and database tests that are within the 'breaking wave' criteria, the value of $\gamma_{\mathrm{d}}$ is determined using Eq. (1.10). This approach assumes that all data should fulfil the TAW (2002) approach exactly (with corrected dimensionless crest height $R^{*}$ as given in
Eq. (1.11)). This assumes that all deviations can be attributed to the influence of water depth. Of course, this is not the case but, as will turn out later, this might explain the deviations to some extent.

The calculated value of $\gamma_{\mathrm{d}}$ for each test is plotted as function of the relative depth $\left(H_{\mathrm{m} 0, \text { toe }} / h_{\mathrm{t}}\right)$ in Figure 14 (Scheldt Flume and OpenFoam) and Figure 15 (CLASH / CLASH-EurOtop database). A value of $\gamma_{\mathrm{d}}$ above 1 indicates that the current formula underestimates and a value below 1 indicates that the formula overestimates the calculated mean overtopping discharges.

The CLASH/CLASH-EurOtop database is shown as three different subsets:

- $\quad$ A basic subset with $R^{*}>0.5$

- Outliers (discussed in Section 5.6)

- $R^{*}<0.5$

Tests with $R^{*}<0.5$ are isolated since the TAW (2002) and EurOtop (2018) predict different overtopping discharges in this domain (see Section 1.3).

In Figure 15, two fits were made for the CLASHEurOtop data: one fit (continuous blue line) based on the above described data and one fit (dashed blue line) where the two test with $H_{\mathrm{m} 0 \text {,toe }} / h_{\mathrm{t}} \approx 0.05$ were not taken into account. As can be seen this does not give a significant difference in the trendlines.

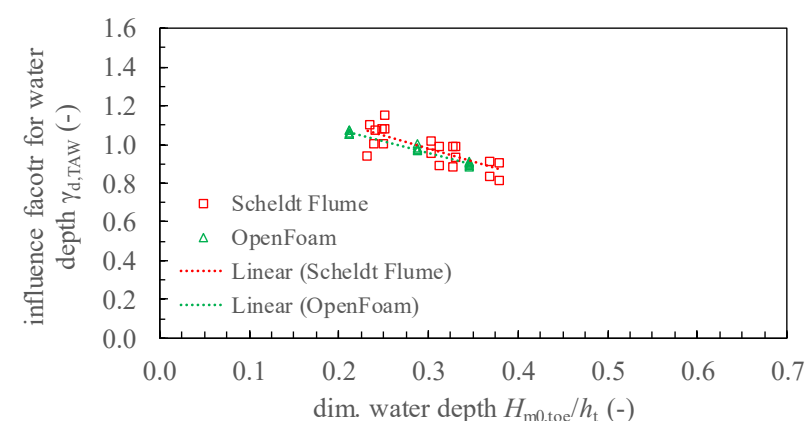

Figure 14. Influence factor for water depth $\gamma_{\mathrm{d}}$ derived with Eq. (1.10) as function of relative depth $H_{\mathrm{m} 0 \text {,toe }} / h_{\mathrm{t}}$ (Scheldt Flume tests and OpenFoam tests).

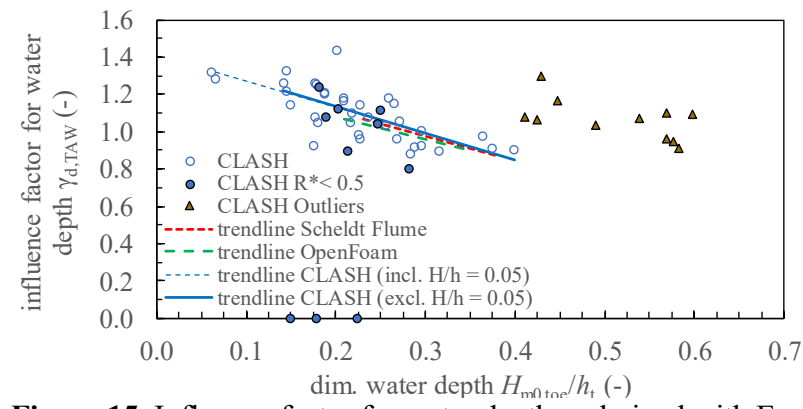

Figure 15. Influence factor for water depth $\gamma_{\mathrm{d}}$ derived with Eq. (1.10) as function of relative depth $H_{\mathrm{m} 0 \text {,toe }} d$ (CLASH/CLASHEurOtop database).

As can be seen there is a relatively high correlation between the relative water depth $\left(H_{\mathrm{m} 0 \text {,toe }} / h_{\mathrm{t}}\right)$ and the calculated influence factor for water depth $\gamma_{\mathrm{d}, \mathrm{TAW}}$. The found linear relation for the three datasets is almost identical as is illustrated by the three fits. The suggested relationship is given by: 


$$
\gamma_{d}=c_{1} \cdot\left(\frac{H_{m 0, t o e}}{h_{t}}\right)+c_{2}
$$

With $c_{1}$ and $c_{2}$ to be estimated based on the available data. The values of $c_{1}$ and $c_{2}$ for the available data sets as well as the proposed values are given Table 7 .

\begin{tabular}{|l|c|c|}
\hline Data set & $\boldsymbol{c}_{\mathbf{1}}$ & $\boldsymbol{c}_{\mathbf{2}}$ \\
\hline Scheldt Flume & -1.35 & 1.38 \\
\hline OpenFoam & -1.20 & 1.32 \\
\hline CLASH/CLASH-EurOtop database & -1.40 & 1.41 \\
\hline proposed & -1.4 & 1.4 \\
\hline
\end{tabular}

Table 7. Derived and proposed values of $c_{1}$ and $c_{2}$ in Eq. (1.12).

\subsection{Projection of suggested influence factor for water depth $Y_{d}$ on all data}

Now it is possible to project Eq. (1.12) on the three databases and see whether the correlation improves. This is shown in Figure 16 and Figure 17. The coefficient of determination $\left(R^{2}\right)$ for each dataset is given in Table 8. As it turns out, the coefficient of determination $R^{2}$ (based on exponential fitting) improves significantly when applying the suggested influence factor for water depth.

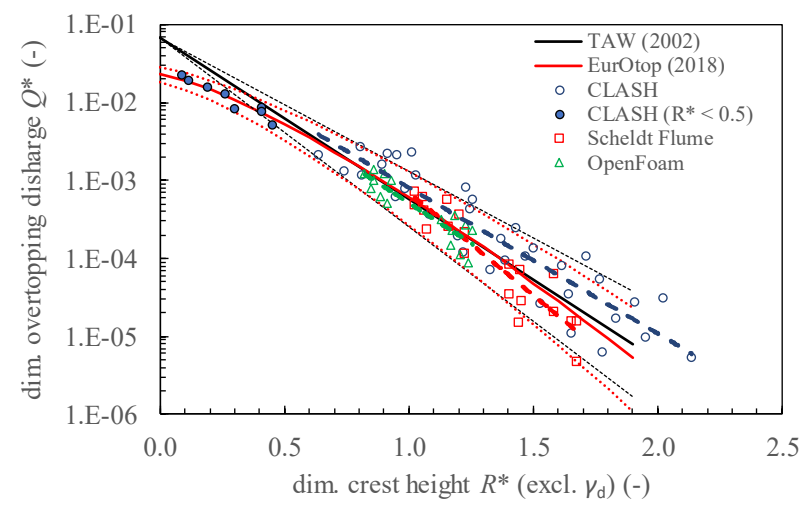

Figure 16. Dimensionless wave overtopping discharge $Q^{*}$ as function of dimensionless crest height $R^{*}$ uncorrected for influence of water depth.

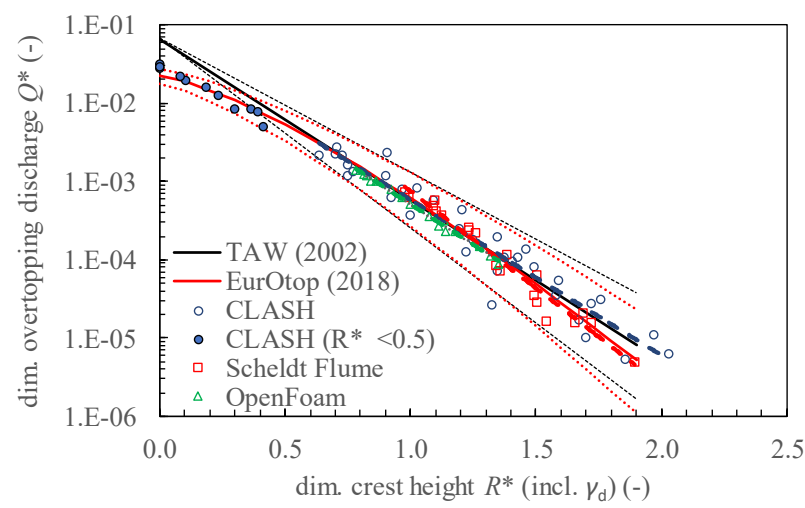

Figure 17. Dimensionless wave overtopping discharge $Q^{*}$ as function of dimensionless crest height $R^{*}$ corrected for influence of water depth.

\begin{tabular}{|l|c|c|}
\hline Data set & $\begin{array}{c}\boldsymbol{R}^{\mathbf{2}} \\
\text { excl. } \boldsymbol{\gamma}_{\mathbf{d}}\end{array}$ & $\begin{array}{c}\boldsymbol{R}^{\mathbf{2}} \\
\text { incl. } \boldsymbol{\gamma}_{\mathbf{d}}\end{array}$ \\
\hline Scheldt Flume & 0.86 & 0.96 \\
\hline OpenFoam & 0.81 & 0.99 \\
\hline CLASH/EurOtop excl $R^{*}<0.5$ & 0.85 & 0.93 \\
\hline All data excl. $R^{*}<0.5$ & 0.81 & 0.94 \\
\hline
\end{tabular}

Table 8. Overview of coefficient of determination $R^{2}$ with and without inclusion of influence factor of depth $\gamma_{\mathrm{d}}$ in TAW (2002) formula.

\subsection{Outliers}

During the analysis eleven tests within the CLASH / CLASH-EurOtop database were considered as outliers and were not considered in the analysis. The outliers consisted of eight tests which are described in Coates et al. (1997), one test which is described in Van der Meer and de Waal (1993) and two tests described in a classified source (id 956) which is not retrieved.

All outliers have a value of $H_{\mathrm{m} 0 \text {, toe }} / h_{\mathrm{t}}>0.4$ (see also Figure 10) and a foreshore slope angle of $\cot \alpha=30$ (exception of one test where $H_{\mathrm{m} 0 \text {,toe }} / h_{\mathrm{t}} \approx 0.6$ and $\cot \alpha=$ 100). This indicates that other potential mechanisms such as shoaling may have played a role here.

In the available reports no values of $T_{\mathrm{m}-1.0}$ at the toe were found indicating that the values of $T_{\mathrm{m}-1.0}$ at the toe of these tests were determined indirectly.

Due to the uncertainty of the quality of these tests (determination of $T_{\mathrm{m}-1.0}$ at the toe), the unknown potential different behaviour for these specific conditions and the fact that these are clearly outliers, it was chosen not to use the identified eleven tests in the analysis in the previous paragraphs.

\section{Discussion}

\subsection{Range of suggested formula}

The datasets, the range of each dataset and the proposed formula (Eq. (1.12)) is given in Figure 18. In this figure the dimensionless parameter $h_{t} / H_{\mathrm{m} 0 \text {,toe }}$ is used instead of $H_{\mathrm{m} 0, \text { toe }} / h_{\mathrm{t}}$ (i.e., the reciprocal of the latter).This figure is used to estimate the upper and lower values for which the proposed formula (Eq. (1.12) can be used.

The lower range for the Scheldt Flume tests, numerical OpenFoam tests and CLASH/CLASH-EurOtop database is at approximately $h_{\mathrm{t}} / H_{\mathrm{m} 0 \text {,toe }} \approx 2.5$ with corresponding influence factor of water depth of $\gamma_{\mathrm{d}} \approx 0.85$.

The higher range for the Scheldt Flume and OpenFoam tests is approximately $h_{\mathrm{t}} / H_{\mathrm{m} 0 \text {,toe }} \approx 4.5\left(\gamma_{\mathrm{d}} \approx 1.1\right)$. The CLASH/CLASH-EurOtop database has a somewhat higher value of $h_{\mathrm{t}} / H_{\mathrm{m} 0 \text {,toe }} \approx 7\left(\gamma_{\mathrm{d}} \approx 1.2\right)$ and even two tests at $h_{\mathrm{t}} / H_{\mathrm{m} 0 \text {,toe }} \approx 16 .\left(\gamma_{\mathrm{d}} \approx 1.3\right)$. The formula is asymptotic which also follows from Eq. (1.12) ):

$$
\gamma_{d}\left(\lim \left(\frac{h_{t}}{H_{m 0, t o e}}\right) \rightarrow \infty\right)=1.4
$$


The amount of data in the range $7<\approx h_{\mathrm{t}} / H_{\mathrm{m} 0 \text {,toe }}$ is limited and therefore predictions in that range $\left(\gamma_{\mathrm{d}} \approx 1.2-\right.$ 1.4) should be taken with care.

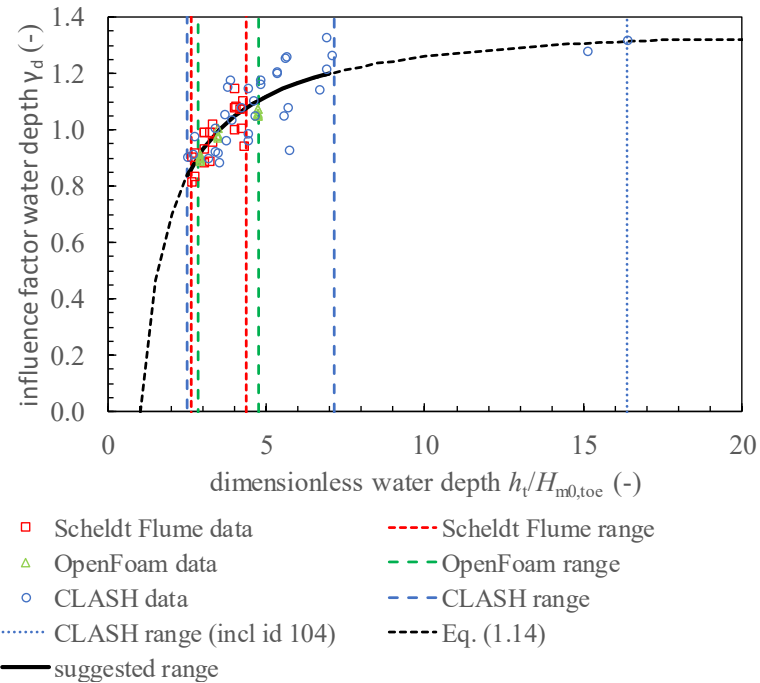

Figure 18. Range of Scheldt Flume tests, OpenFoam tests and CLASH/CLASH-EurOtop database.

\subsection{Applicability to TAW (2002) and EurOtop (2018) formulas}

Eq. (1.12) and proposed values of $c_{1}$ and $c_{2}$ are derived based on the TAW (2002) formula. For values of $R^{*}>0.5$ the TAW (2002) and EurOtop (2018) are almost identical implying that Eq. (1.12) and proposed values of $c_{1}$ and $c_{2}$ are also applicable for the EurOtop (2018) formula in this range.

However, for relatively small values of $R^{*}$, TAW (2002) and EurOtop (2018) formulas deviate significantly. As can be seen in Figure 17, the predictions of the CLASH data, while applying Eq. (1.12) in that range are still in the same range as the EurOtop (2018) formula. This means that also for this range Eq. (1.12) can be applied to the EurOtop (2018) formula. It is however noted that the value of $\gamma_{\mathrm{d}}$ should be taken to the power 1/1.3 if applied in combination with the EurOtop (2018) expression.

\subsection{Implications}

The influence of the water depth on the wave overtopping discharge, as identified and explored in this paper, has three significant implications.

The first implication is the new insight that the water depth at the toe of a structure can already start to influence wave overtopping characteristics when the foreshore is still classified as deep, according to Table 2. This is an important aspect that should be modelled correctly when designing or assessing hydraulic structures using design formulas or physical or numerical models.

The second implication is the recommendation to include the influence of the water depth in the wave overtopping prediction formulas. One way to do this is to introduce an influence factor for water depth, comparable with the already existing influence factors for berms, roughness, crest wall elements and oblique wave attack such as suggested in this paper. However, it is still uncertain how the combination of all these influence factors will perform. When implementing the suggested influence factors in the TAW (2002) or EurOtop (2018) formulas, the new formulas need to be continuous with other formulas in other domains (such as the formula for non-breaking waves (Eq. (1.2) and Eq. (1.4)) and the formula for very shallow foreshores as given in EurOtop (2018) (not given in this paper). Also, it should be noted that the influence of the water depth for the non-breaking part of the formulas (Eq. (1.2) and Eq. (1.4)) has not been investigated yet.

The third implication is the influence on earlier performed research. Generally, influence factors for berms, roughness, crest walls and oblique wave attack are determined by comparing results of physical model tests with the prediction formulas or by comparing with reference tests. Differences are usually contributed to the parameter of interest such as berms, roughness, oblique wave attack or crest elements. Potentially, these research outcomes are influenced by the influence of the water depth, especially when no reference tests with the same water depth were performed. This might have led to 'contaminated' values for the influence factors of berms, roughness, oblique wave attack or crest elements. It is therefore recommended to re-evaluate these influence factors.

\section{Conclusions}

The influence of the water depth in relatively deep water is determined by performing physical model tests in the Scheldt Flume of Deltares, numerical model tests with the use of OpenFoam and a desk study based on selected data from the CLASH and CLASH-EurOtop database. Based on these studies the following influence factor for water depth is suggested:

$$
\gamma_{d}=c_{1} \cdot\left(\frac{H_{m 0, \text { toe }}}{h_{t}}\right)+c_{2}
$$

With $\gamma_{\mathrm{d}}$ being the influence factor for water depth (-), $H_{\mathrm{m} 0 \text {,to }}$ the spectral wave height at the toe of the structure $(\mathrm{m}), h_{\mathrm{t}}$ the water depth at the toe of the structure $(\mathrm{m})$ and $c_{1}$ and $c_{2}$ empirically derived coefficients (-): $c_{1}=-1.4$ and $c_{2}=1.4$. It is suggested to implement this influence factor for water depth in the 'breaking part' of the TAW (2002) and EurOtop (2018) formulations leading to the following equations:

Suggested modified TAW (2002) formula for breaking waves:

$$
\frac{q}{\sqrt{g \cdot H_{m 0}^{3}}}=\frac{0.067}{\sqrt{\tan \alpha}} \cdot \gamma_{b} \cdot \xi_{m-1,0} \cdot e^{-a \frac{R_{c}}{H_{m 0}} \cdot \frac{1}{\xi_{m-1,0} \cdot \gamma_{b} \cdot \gamma_{f} \cdot \gamma_{\beta} \cdot \gamma_{v} \cdot \gamma_{d}}}
$$

Suggested modified EurOtop (2018) formula for breaking waves:

$$
\frac{q}{\sqrt{g \cdot H_{m 0}^{3}}}=\frac{c}{\sqrt{\tan \alpha}} \cdot \gamma_{b} \cdot \xi_{m-1,0} \cdot e^{-\left(d \cdot \frac{R_{c}}{H_{m 0}} \cdot \frac{1}{\xi_{m-1,0} \cdot \gamma_{b} \cdot \gamma_{f} \cdot \gamma_{\beta} \cdot \gamma_{v} \cdot \gamma_{d}}\right)^{1.3}}
$$


With values of $a, c$ and $d$ given in Table 1 . This adjustment is recommended for situations with:

$$
2.5 \leq h_{\mathrm{t}} / H_{\mathrm{m} 0 \text {,toe }} \leq 7 \quad\left(0.85 \leq \gamma_{\mathrm{d}}<1.2\right)
$$

A value of $\gamma_{\mathrm{d}}=1$, which is the current practice in the TAW (2002) and EurOtop (2018) formulas, is obtained for a dimensionless water depth of $h_{\mathrm{t}} / H_{\mathrm{m} 0 \text {,toe }}=3.5$. Note that the values obtained for $\gamma_{\mathrm{d}}$ should be taken to the power 1/1.3 if applied in combination with the EurOtop (2018) expression, rather than with the TAW (2002) formula.

\section{Acknowledgements}

The research is funded by Rijkswaterstaat which is part of the Dutch Ministry of Infrastructure and Water Management.

\section{References}

1. Altomare, C., T. Suzuki, X. Chen, T. Verwaest, and A. Kortenhaus (2016). Wave overtopping of sea dikes with very shallow foreshores. Coastal Engineering 116: 236-257.

2. Battjes, J.A., H.W. Groenendijk (2000). Wave height distribution on shallow foreshores, Coastal Engineering, 40 (3): 161-182

3. Chen, X., B. Hofland and W.S.J. Uijttewaal, Maximum overtopping forces on a dike-mounted wall with a shallow foreshore. Coastal Engineering, 116 (2016): 89-102.

4. EurOtop (2018). Manual on wave overtopping of sea defences and related structures. An overtopping manual largely based on European research, but for worldwide application.

www.overtopping-manual.com.

5. Coates T.T., R.J. Jones and P.F.D. Bona (1997). Wind/swell seas and steep approach slopes, Hydraulic Research Institute Wallingford. Technical Report on wave flume studies, TR24.

6. Deltares (2015). Influence of water depth at wave runup and wave overtopping. Deltares report 1220038 010-VEB-0009, November 2015.

7. Deltares (2018). Influence of water depth at wave overtopping: measurement report (in Dutch, original title: Invloed waterdiepte op golfoverslag: meetverslag golfoverslag proeven). Deltares report 11202189-012-ZWS-0001, December 2018.

8. Deltares (2019). Influence of water depth at wave overtopping, numerical study (in Dutch: Invloed waterdiepte op golfoverslag, numerieke studie). Deltares report 11203682-015-ZWS-0001, October 2019.

9. Goda, Y. (2009). Derivation of unified wave overtopping formulas for seawalls with smooth, impermeable surfaces based on selected CLASH datasets. Coastal Engineering 56: 385-399. https://doi.org/10.1016/j.coastaleng.2008.09.007.

10. Hofland, B., X. Chen, C. Altomare, P. Oosterlo (2017). Prediction Formula for the Spectral Wave Period Tm-1,0 on Mildly Sloping Shallow Foreshores, Coastal Engineering 123: 21-28. https://doi.org/10.1016/j.coastaleng.2017.02.005.

11. HWBP (2019). Probabilistic design of crest height (In Dutch. Original title: Redeneerlijn probabilistisch bepalen kruinhoogte). HWBP memo, November 2019.

12. Jacobsen, N. G., D.R. Fuhrman, and J. Fredsøe (2012). A wave generation toolbox for the opensource CFD library: OpenFoam ${ }^{\circledR}$. International Journal for numerical methods in fluids, 70(9): 1073-1088.

13. MinI\&W (2019), Procedure safety assessment primary flood defences. (In Dutch. Original titel: Regeling veiligheid primaire waterkeringen 2017 Bijlage I Procedure). Ministerie van Infrastructuur en Milieu, 29 January 2019.

14. Oumeraci, H., H. Schüttrumpf, J. Möller, and M. Kudella (2001). Loading of the Inner Slope of Seadikes by Wave Overtopping, Report 858, Leichtwei $\beta$ Institute for Hydraulics, Technical University of Braunschweig, Germany.

15. Paulsen, B. T., H. Bredmose, and H.B. Bingham, (2014). An efficient domain decomposition strategy for wave loads on surface piercing circular cylinders. Coastal Engineering 86: 57-76.

16. Rijkswaterstaat (2014). Manual design based on flood probability (In Dutch. Original title: Handreiking ontwerpen met overstromingskansen, OI 2014v4), February 2017.

17. Schüttrumpf H. and J. Murphy (2000). 3D Model Tests on Wave Overtopping For 1:6 Dike, Opticrest, MAS3-CT97-0116, LWI-report No.: 857, September 2000.

18. Schüttrumpf, H. (2001). Wave overtopping at seadikes - Experimental and theoretical research (in German. Original title: Wellenüberlaufströmung bei Seedeichen - Experimentelle und theoretische Untersuchungen) $\mathrm{PhD}$ study, Leichtwei $\beta$ Institute for Hydraulics, Technical University of Braunschweig, Germany.

19. Steendam, G.J., J.W. van der Meer, H. Verhaeghe, P. Besley, L. Franco and M.R.A. van Gent (2004). The international database on wave overtopping. Coastal Engineering (2004): 4301- 4313, April 2005.

20. Szmytkiewicz, M., R.B. Zeidler and K.W. Pilarczyk (1994). Irregular wave run-up on composite rough slopes, Proceedings Coastal Dynamics 1994.

21. TAW (2002). Technical report Wave Run-up and Wave Overtopping at Dikes. Technical Advisory Committee on Flood Defence, Delft, May 2002.

22. Van der Meer, J.W. and J.P. De Waal (1993). Watermovement on slopes, influence of various aspects (In Dutch. Original title: Waterbeweging op taluds, Invloed van berm, ruwheid, ondiep voorland en scheve lang- en kortkammige golfaanval, Waterloopkundig Laboratorium, Verslag H1256.

23. Van der Meer, J.W., H. Verhaeghe and G.J. Steendam (2009). The new wave overtopping database for coastal structures. Coastal Engineering (2009), 56: 108-120.

24. Van der Meer, J.W., J.W. Nieuwenhuis, G.J. Steendam, M.J.J. Reneerkens, H.J. Steetzel and G.Ph. 
van Vledder (2019). Wave overtopping measurements at a real dike. Proceedings Coastal Structures Conference, 2019, Hannover.

25. Van Gent, M.R.A. (1999). Physical model investigations on coastal structures with shallow foreshores; 2D model tests with single and doublepeaked wave energy spectra, Delft Hydraulics Report H3608, December 1999, Delft.

26. Van Steeg P., M. Klein Breteler and Y. Provoost (2016). Large-scale physical model tests to determine influence factor of roughness for wave run-up of channel shaped block revetments. Proceedings $6^{\text {th }}$ Int. Conf. on the Application of Physical Modelling in Coastal and Port Engineering and Science (Coastlab16). Ottawa, Canada, May 10-13, 2016.

27. Victor L. and P. Troch (2011). Wave Overtopping at Smooth Impermeable Steep Slopes with Low Crest Freeboards. Journal of Waterway, Port, Coastal and Ocean Engineering 138 (5) September 2012.

28. WL (1993). Wave run-up and wave overtopping at dike (in Dutch, original title: Golfoploop en golfoverslag bij dijken). WL | Delft Hydraulics report H638, April 1993.

29. WL (1997). Wave run-up and wave overtopping at levees, backgrounds (in Dutch, original title: Golfoploop en golfoverslag bij dijken, Projectverslag: Achtergronden bij aanpassing van notitie "Golfoploop en golfoverslag bij dijken", H638, april 1993). WL | Delft Hydraulics memo $H$ 2458/H3051, June 1997.

30. Zelt, J.A. and J.E Skjelbreia (1993). Estimating incident and reflected wave fields using an arbitrary number of wave gauges. In Proceedings $23^{\text {rd }}$ Int. Conf. on Coastal Engineering 1992: 777-789. 